\title{
Holmes-Gang syndrome
}

INSERM

\section{Source}

INSERM. (1999). Orphanet: an online rare disease and orphan drug data base. Holmes-

Gang syndrome. ORPHA:93970

Holmes-Gang syndrome is an X-linked mental retardation (XLMR) syndrome belong ing to the group of conditions characterised by the association of intellectual deficit with hypotonic facies (Mental retardation, X-linked-hypotonic facies; see this term). 